\title{
Three-Dimensional Measurements of Flow in Uncased Wells Completed in Basalt, Mountain Home Air Force Base, Idaho, March 2000
}

Water-Resources Investigations Report 01-4259

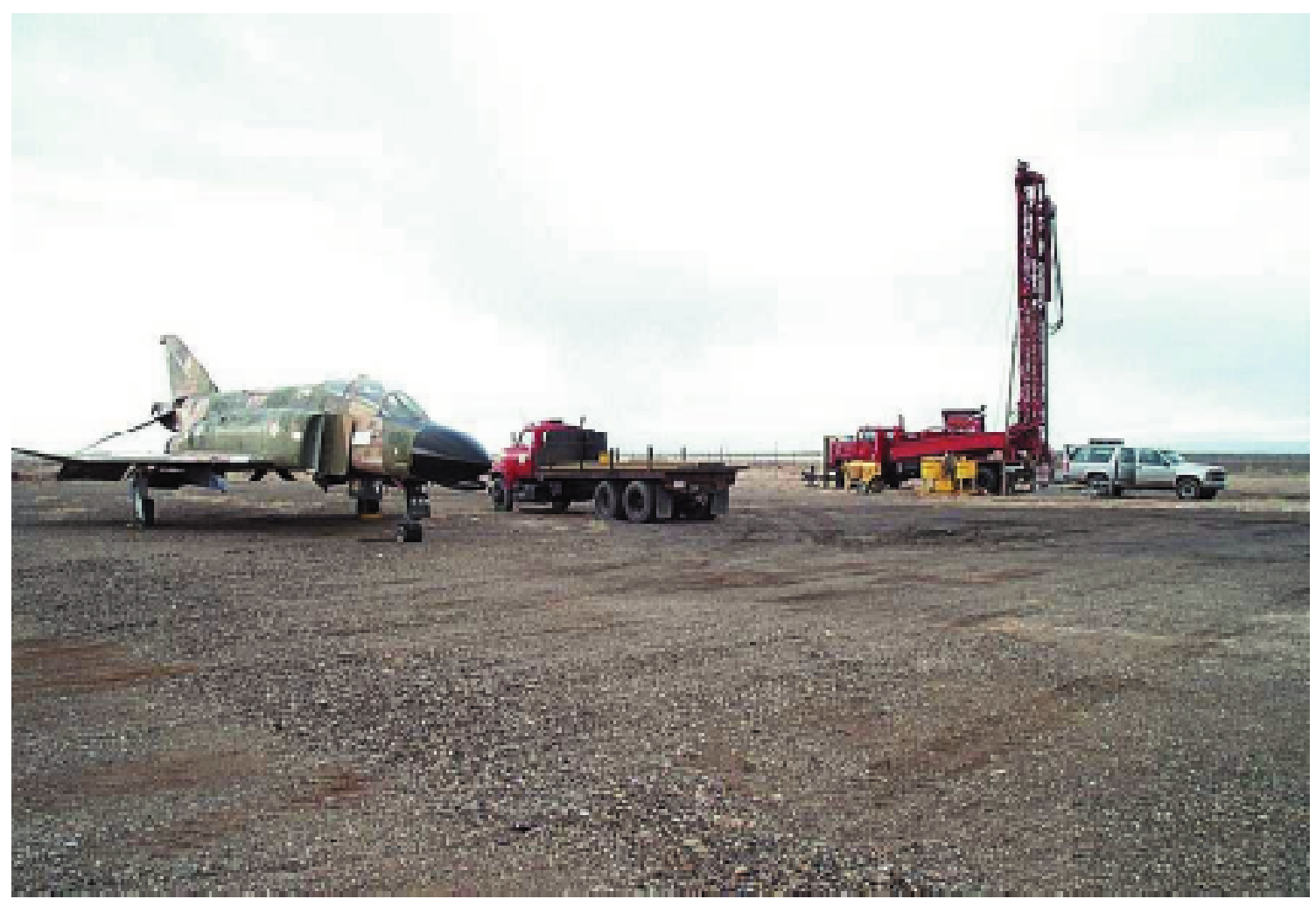

Western Region Research Drilling Unit and portable logging unit recording flow data in MW3-2, Mountain Home Air Force Base, Idaho, on March 6, 2000. (Photo by Mark W. Newhouse, U.S. Geological Survey) 


\section{Three-Dimensional Measurements of Flow in Uncased Wells Completed in Basalt, Mountain Home Air Force Base, Idaho, March 2000}

By M.W. Newhouse and R.T. Hanson

Water-Resources Investigations Report 01-4259

Prepared in cooperation with the Department of the Air Force 


\section{U.S. DEPARTMENT OF THE INTERIOR}

GALE A. NORTON, Secretary

\section{U.S. GEOLOGICAL SURVEY}

Charles G. Groat, Director

Any use of trade, product, or firm names in this publication is for descriptive purposes only and does not imply endorsement by the U.S. Government.

Additional information can be obtained from: Copies of this report also are available in PDF

District Chief

U.S. Geological Survey

230 Collins Road

Boise, ID 83702-4520

http://idaho.usgs.gov format, which can be viewed using Adobe

Acrobat Reader, at URL:

http://idaho.usgs.gov/public/reports.html 


\section{CONTENTS}

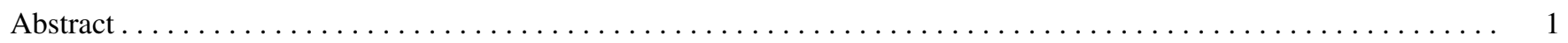

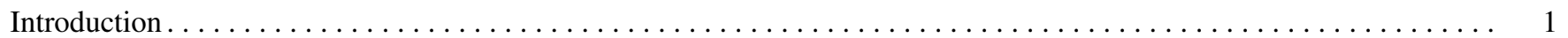

Description of the borehole acoustic doppler velocimeter $\ldots \ldots \ldots \ldots \ldots \ldots$

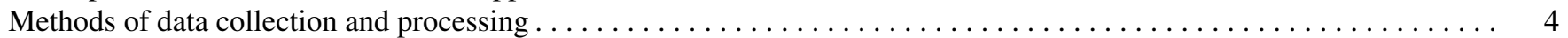

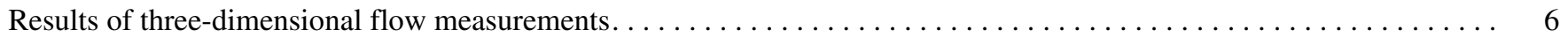

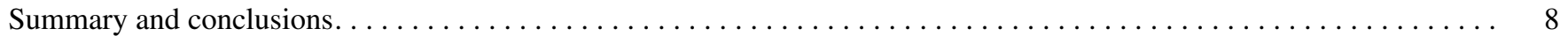

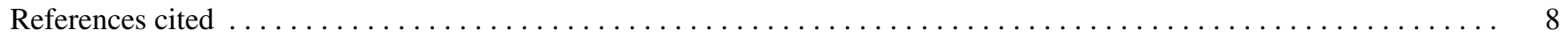

\section{FIGURES}

1. Map showing location of study area, wells, 1990 water levels, and direction of ground-water movement near

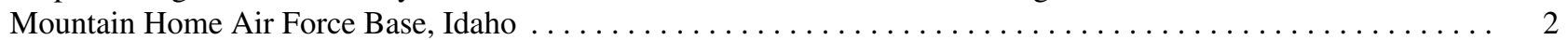

2. Map showing location of monitoring wells on the Mountain Home Air Force Base, Idaho $\ldots \ldots \ldots$

3. Diagram showing borehole acoustic doppler velocimeter and probe $\ldots \ldots \ldots \ldots$

4. Diagram showing velocity-vector definitions used for intraborehole flow measured by the borehole acoustic

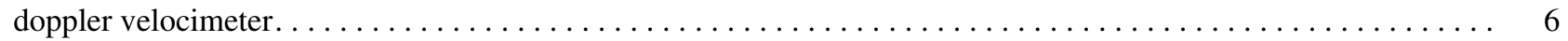

5-9. Graphs showing:

5. Geophysical logs for MW11-2, 350 to 450 feet, Mountain Home Air Force Base, Idaho. . . . . . . . . . . 9

6. Geophysical logs for MW3-2 (MW3-2-030100), 350 to 450 feet, March 1, 2000,

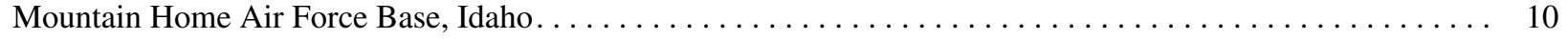

7. Geophysical logs for MW3-2 (MW3-2-030300), 350 to 450 feet, March 3, 2000,

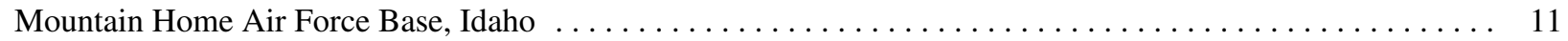

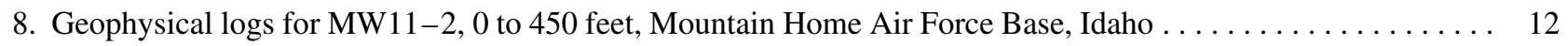

9. Geophysical $\operatorname{logs}$ for MW3-2, 0 to 450 feet, Mountain Home Air Force Base, Idaho . . . . . . . . . . . . . 13

\section{TABLES}

1. Flow measurements in MW11-2, Mountain Home Air Force Base, Idaho . . . . . . . . . . . . . . . . 6

2. Flow measurements in MW3-2 (MW3-2-030100), March 1, 2000, Mountain Home Air Force Base, Idaho . . . . 7

3. Flow measurements in MW3-2 (MW3-2-030300), March 3, 2000, Mountain Home Air Force Base, Idaho . . . . 7

\section{CONVERSION FACTORS AND VERTICAL DATUM}

\begin{tabular}{rcl}
\hline Multiply & By & To obtain \\
\hline cubic inch $\left(\mathrm{in}^{3}\right)$ & 16.39 & cubic centimeter \\
foot $(\mathrm{ft})$ & 0.3048 & meter \\
foot per second $(\mathrm{ft} / \mathrm{s})$ & 0.3048 & meter per second \\
inch (in.) & 25.4 & millimeter \\
mile (mi) & 1.609 & kilometer \\
\hline
\end{tabular}

Sea level: In this report, "sea level" refers to the National Geodetic Vertical Datum of 1929_a geodetic datum derived from a general adjustment of the first-order level nets of the United States and Canada, formerly called Sea Level Datum of 1929. 


\title{
Three-Dimensional Measurements of Flow in Uncased Wells Completed in Basalt, Mountain Home Air Force Base, Idaho, March 2000
}

\author{
By M.W. Newhouse and R.T. Hanson
}

\section{Abstract}

Several ground-water monitoring wells on the Mountain Home Air Force Base in southwestern Idaho were constructed in February 2000 to replace existing monitoring wells that became ineffective as a result of declining water levels. Upon completion of the replacement wells, borehole geophysical logs were collected, including natural gamma radiation, electromagnetic induction, caliper, fluid temperature, and resistivity. A prototype borehole acoustic doppler velocimeter (B-ADV) was used to make experimental three-dimensional measurements of lateral and vertical flow in two of the replacement wells, MW11-2 and MW3-2, each 450 feet deep, to better understand ground-water flow in the basalt underlying this area.

Measurements indicated two independent flow zones in each well: unit B, from about 380 to about 415 feet below land surface, and unit $\mathrm{C}$, from about 415 to about 430 feet below land surface. In each well, direction of flow in unit $\mathrm{B}$ was north-northwest toward Canyon Creek and, in unit C, south-southwest toward the Snake River. Measurements also indicated downward intraborehole flow in both wells. Unit B appeared to represent a local-scale flow regime; unit $\mathrm{C}$ appeared to represent a regional flow regime.

This information suggests the existence of a complex three-dimensional hydrogeologic setting that cannot be discriminated easily on conventional waterlevel maps. Although data from only two wells are insufficient to construct a conceptual model of the ground-water flow regime, these experimental results demonstrate the capability of the B-ADV to obtain detailed flow measurements that, combined with data from other types of geophysical logs, discrete measurements of hydraulic head, and water chemistry, would aid in future studies and management of the ground-water resources, including contaminant transport and remediation.

\section{INTRODUCTION}

Several ground-water monitoring wells on the Mountain Home Air Force Base (MHAFB) in southwestern Idaho (fig. 1) were constructed by the U.S. Geological Survey (USGS), in cooperation with the Department of the Air Force, in February 2000 to replace existing monitoring wells that became ineffective as a result of declining water levels. Upon completion of the replacement wells, borehole geophysical logs were collected, including natural gamma radiation, electromagnetic induction, caliper (borehole diameter), fluid temperature, and resistivity. In addition to information gained from these logs, more definitive information about the flow regime in the basalt ground-water system underlying the MHAFB is needed to better understand contaminant transport.

Conventional tools for measuring flow within a borehole include the impeller flowmeter, heat-pulse flowmeter, colloidal boroscope, and hydrophysical logging. Most of these tools are limited in their dynamic range and cannot simultaneously measure lateral and vertical flows through the borehole. The development of the borehole acoustic doppler velocimeter (B-ADV) allows direct three-dimensional (3-D) measurements of borehole flow across a range of velocities from 0.0003 to $8 \mathrm{ft} / \mathrm{s}$. The B-ADV was first successfully applied to a coastal monitoring well completed in an alluvial aquifer in 1996 (Ursic, 1996). Since then, modifications have improved the accuracy of depth placement in the borehole and the stability of the B-ADV during data acquisition. More recently, the B-ADV has proven to be a valuable geophysical tool for measuring flow in coastal aquifers in California (Newhouse and Hanson, 2000) and carbonate aquifers in Indiana and Tennessee (Wilson and others, 2001).

This report presents data acquired from an experimental application of the B-ADV to measure lateral and vertical flows through two of the recently completed, uncased wells on the MHAFB-MW11-2 and MW3-2 (fig. 2) during March 2000. The purpose of this report is 

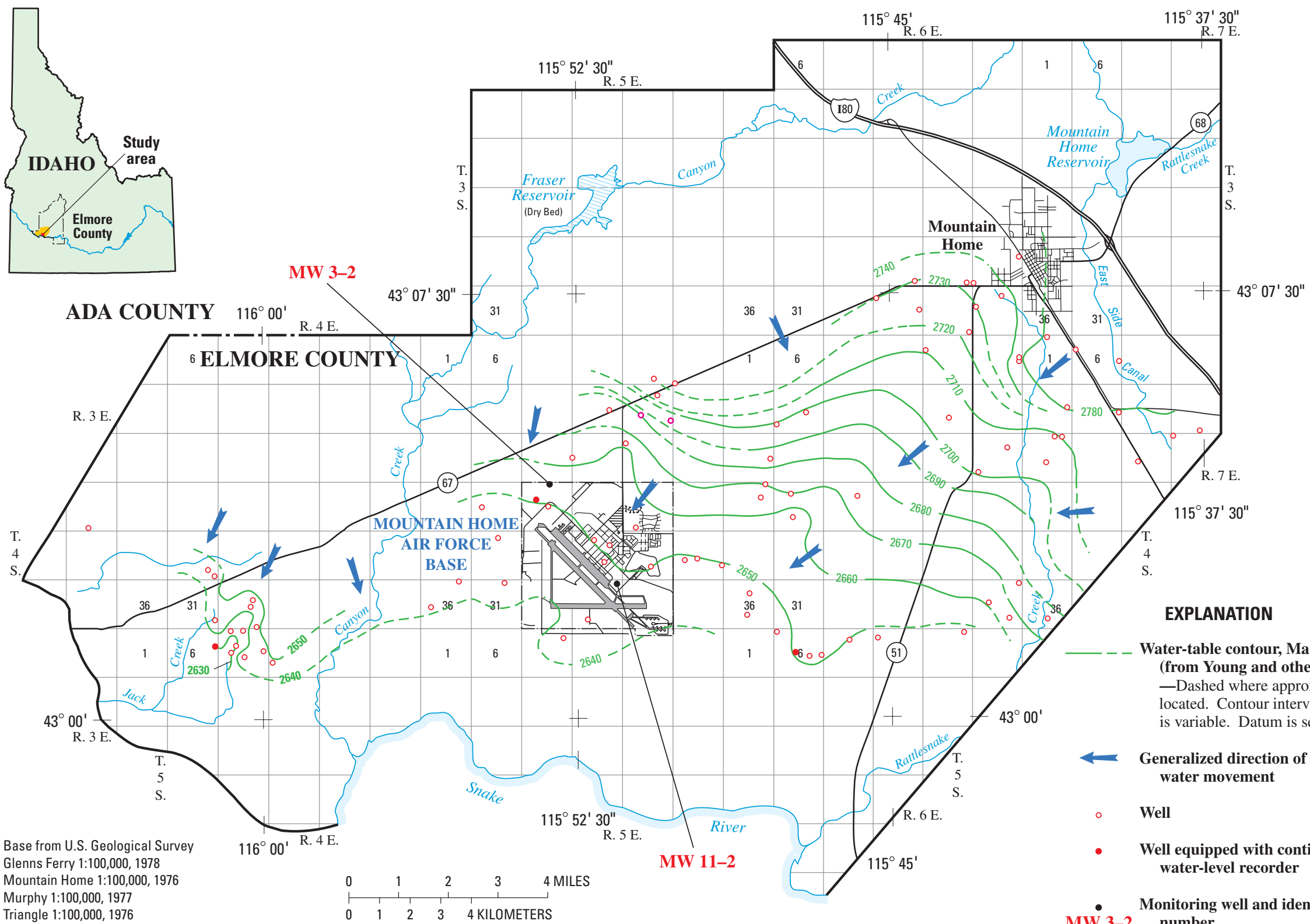

\section{EXPLANATION}

Water-table contour, March 1990 (from Young and others, 1992) -Dashed where approximately located. Contour interval, in feet, is variable. Datum is sea level

$\leftarrow$ Generalized direction of groundwater movement

$\circ \quad$ Well

- Well equipped with continuous water-level recorder

MW 3-2 $\begin{gathered}\text { Monitoring well and identification } \\ \text { number }\end{gathered}$

Figure 1. Location of study area, wells, 1990 water levels, and direction of ground-water movement near Mountain Home Air Force Base, Idaho. 


\section{EXPLANATION}

MW 3-2

Monitoring well and identification number

Base from U.S. Geological Survey

digital data, 1:24,000; Crater Rings

SE, 1992; Crater Rings SW, 1992;

North American Datum (NAD) of 1983

Universal Transverse Mercator (UTM)

projection, Zone 11

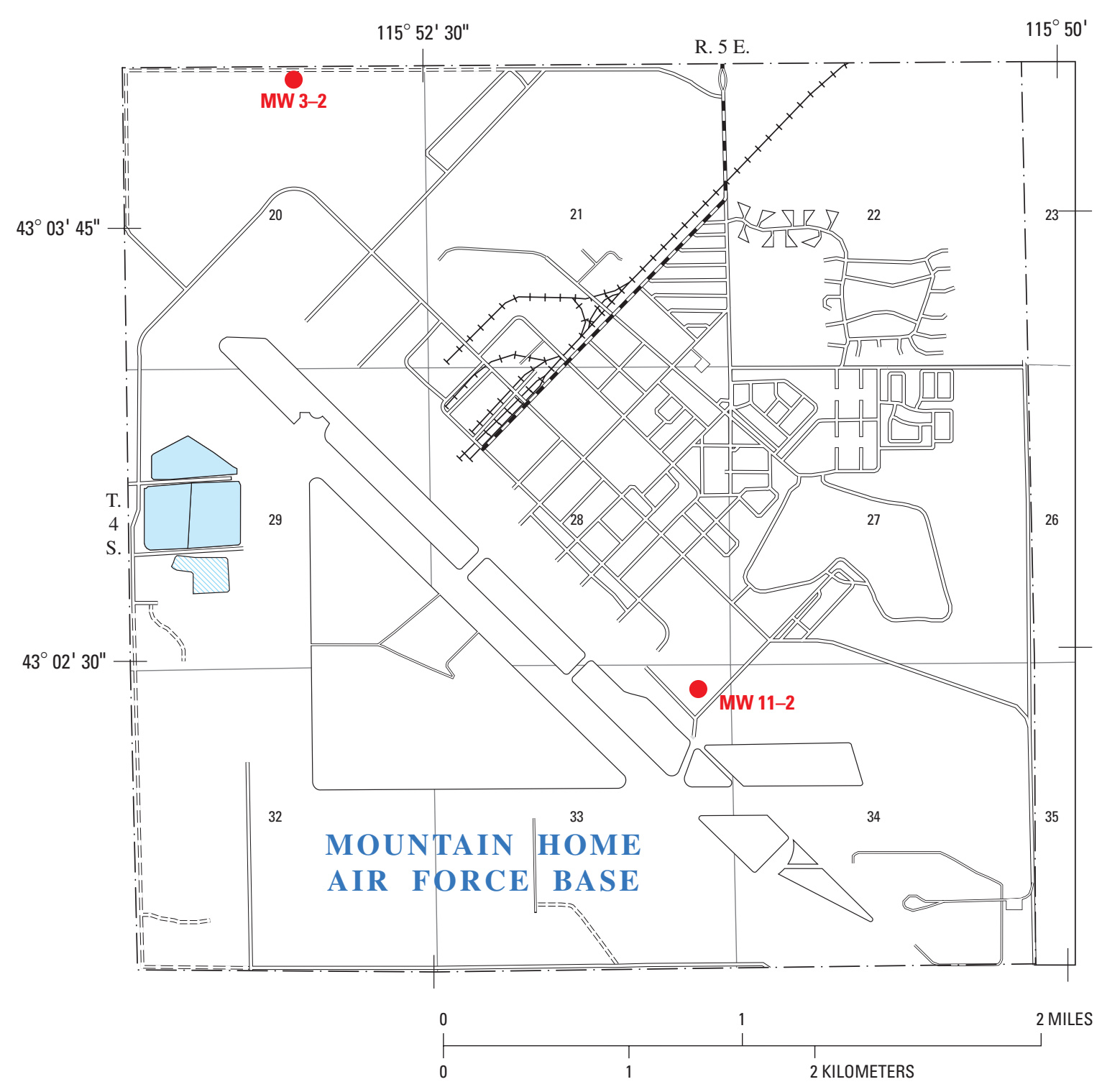

Figure 2. Location of monitoring wells on the Mountain Home Air Force Base, Idaho. 
to describe methodology, data collection procedures, and $\mathrm{B}-\mathrm{ADV}$ results from these wells.

\section{DESCRIPTION OF THE BOREHOLE ACOUSTIC DOPPLER VELOCIMETER}

The suite of B-ADV current meters has been developed primarily for oceanographic and surfacewater applications. A surface-water tool was modified for borehole application during the mid-1990s for the U.S. Environmental Protection Agency. The B-ADV tool is approximately $4 \mathrm{ft}$ long and $3 \mathrm{in}$. in diameter (fig. 3). It is deployed with a standard, four-conductor cable and drawworks and runs on DC power. During logging, a binary signal is transmitted from digital processors in the tool through the conductor cable and an RS-232 serial port connection to DOS-based acquisition software. The data-acquisition software is menu driven with adjustable real-time graphics and digital display of velocity and related data-quality attributes.

Inside the B-ADV tool housing, the electronics are separated into upper and lower sections. The upper section contains the digital-processing electronics. The lower section contains a compass/tilt sensor and probe electronics. The compass/tilt sensor is a flux-gate magnetometer and maintains a fixed alignment with respect to the B-ADV probe. Directional data from the magnetometer can be processed with resulting velocity vectors recorded in the east, north, and up directions. The B-ADV probe is mounted externally at the bottom of the tool housing along with a guard cage to protect the probe from physical damage during deployment in the borehole.

The acoustic probe consists of one centrally mounted acoustic emitter and three receivers located on radial arms (fig. 3). The sampling volume is roughly cylindrical and is a function of the diameter of the transmit transducer ( $0.177 \mathrm{in}$.) and user-defined parameters of transmitter pulse length and receiver window length. The focal point of the sampling volume is approximately $1.9 \mathrm{in}$. in front of the acoustic emitter, and the volume ranges from 0.008 to $0.028 \mathrm{in}^{3}$ (fig. 3).

The B-ADV, like the ADV in surface-water applications, does not measure fluid velocity directly; rather, it measures the velocity of suspended particles in the water column that pass through the sampling volume. In essence, the B-ADV is a particle tracker; therefore, it is assumed that suspended particles in the water column are entrained with the ground-water flow and represent the magnitude and direction of fluid flow in the borehole. Real-time graphic and tabular displays in the data-acquisition software allow the user to monitor velocities, data quality, and stability of the acoustic environment. The velocity range for borehole flow measurements can span four orders of magnitude from 0.0003 to $8 \mathrm{ft} / \mathrm{s}$. Dynamic range is a function of the user-specified acquisition configurations that are dependent upon the velocity flow regime. In each sampling configuration, the velocity range for the sampling environment must be defined. If the true velocity is close to the user-specified velocity range, less noise relative to tracked particles will be acquired and better correlation of the acoustic signal will be achieved.

Though the B-ADV is a useful tool with a wide variety of applications, it does have limitations. For the prototype, maximum depth of submergence is about $200 \mathrm{ft}$. The tiny ceramics that house the acoustic sensors would implode under greater pressures. The RS-232 communications method is only useful to a total cable length of about $400 \mathrm{ft}$. Longer cables would result in signal degradation and a loss of data. Tool housing and probe cage outer diameter limit the deployment of the B-ADV to open boreholes and cased wells with a diameter of 4 in. or larger.

\section{METHODS OF DATA COLLECTION AND PROCESSING}

At each of the two wells used for experimental application of the B-ADV, the temperature and salinity of the borehole fluid were measured from a water sample bailed from the well. The temperature and salinity of the borehole fluid were entered into the B-ADV configuration files to calculate the acoustic velocity of water with that temperature and salinity. The B-ADV then was lowered into the borehole and a diagnostic check of the probe alignment was performed. Probe alignment is a quality-assurance check that is required for proper probe function.

Geophysical logs that were completed prior to the B-ADV log were used to help design the measurement strategy and locate possible zones of ground-water flow in the borehole. B-ADV measurement points were selected where the caliper logs indicated the presence of significant fractures and the gamma logs indicated that the fractures were at major lithologic contacts. The B-ADV was moved slowly between stationary measurement locations within the well to minimize impact on ambient flows. Data were collected over several minutes, at 


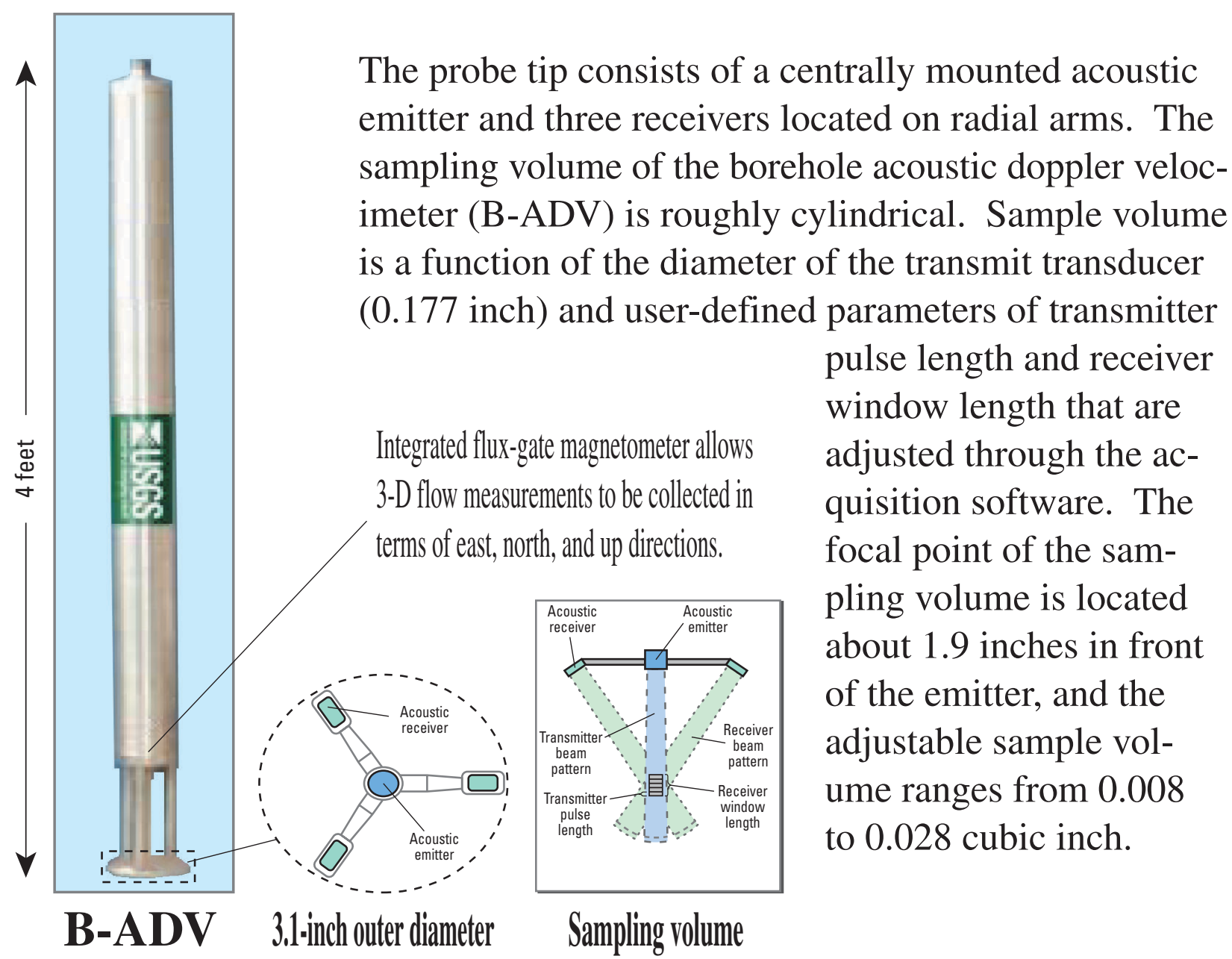

Figure 3. Borehole acoustic doppler velocimeter and probe.

predetermined depths, to create a 3-D flow profile. Flow velocities were graphically monitored to assess the stability of borehole flow, and measurements began once borehole flow restabilized from moving the velocimeter into place.

During data acquisition, two attributes were recorded to monitor the quality and reliability of data: the signal-to-noise ratio (SNR) and the data correlation (COR). SNR is the ratio of the strength of the emitted acoustic pulse and the received acoustic reflection, measured in decibels. The COR is an indicator of how closely one measurement relates to the next and is a dimensionless parameter. A poor COR may be the result of bubbles in the water, turbulence or swirling flow, a low concentration of particles in the water, or an insufficient velocity range set in the user-defined acquisition parameters.
Minimum requirements for data processing are an SNR of 5 and a COR of 70 for each vector (east, north, and up). For this study, data for each depth that met these quality requirements were subsequently filtered out of the entire data set for further calculations. Next, the mean velocity for each direction was calculated, and any values outside two standard deviations from the mean were removed. This removes any velocity outliers from the final calculation of average velocity. Finally, east, north, and up vector data for each depth were averaged with vector sums and directions were computed for analysis.

The presentation of flow data is a combination of lateral (red) and vertical (blue) velocities (fig. 4). Lateral velocities lie in a single horizontal plane and are described in terms of magnitude and direction, or azimuth (red). Vertical velocities are described in terms of 
magnitude and dip angle (blue). Downward flow has a negative value and a dip angle between 91 and 180 degrees. Upward flow has a positive value and a dip angle between 0 and 89 degrees. A dip angle of 90 degrees indicates purely horizontal flow with no vertical component (fig. 4).

\section{RESULTS OF THREE-DIMENSIONAL FLOW MEASUREMENTS}

The ability to measure horizontal flow independently from vertical flow is a unique and important feature of the B-ADV. Horizontal flows can reveal the direction and speed of migrating contamination plumes, and vertical flows can reveal possible cross contamination between different aquifer systems penetrated by a well bore.

MW11-2 is located approximately 3 mi north of the Snake River and 5 mi east of Canyon Creek (fig. 1). Total depth of this well is about $450 \mathrm{ft}$ below land surface. B-ADV data are presented in table 1 for depths 366 to $430 \mathrm{ft}$. Two relatively high-flow zones with different azimuths are evident at around 390 to
$395 \mathrm{ft}$ and 415 to $425 \mathrm{ft}$, separated by a zero- to lowflow zone at $400 \mathrm{ft}$. Relatively slow lateral velocity at $400 \mathrm{ft}$ is evident in a relatively competent and presum-

Table 1. Flow measurements in MW 11-2, Mountain Home Air Force Base, Idaho

[Flow units are grouped by similar azimuths and depths; depth, feet below land surface; ft/s, feet per second; deg, degrees; A, B, C, water-bearing zones; - , unassigned; *, relatively high-flow zone; **, relatively low-flow zone]

\begin{tabular}{lcccccc}
\hline \multicolumn{1}{c}{ Depth } & $\begin{array}{c}\text { Lateral } \\
(\mathrm{ft} / \mathbf{s})\end{array}$ & $\begin{array}{c}\text { Vertical } \\
(\mathrm{ft} / \mathbf{s})\end{array}$ & $\begin{array}{c}\text { Bulk } \\
(\mathrm{ft} / \mathbf{s})\end{array}$ & $\begin{array}{c}\text { Azimuth } \\
\text { (deg) }\end{array}$ & $\begin{array}{c}\text { Flow } \\
\text { unit }\end{array}$ & $\begin{array}{c}\text { Dip } \\
(\mathbf{d e g})\end{array}$ \\
\hline 366.01 & 0.0038 & -0.0134 & 0.0139 & 86 & $\mathrm{~A}$ & 164 \\
368.03 & .0025 & -.0142 & .0144 & 108 & $\mathrm{~A}$ & 170 \\
370.00 & .0005 & -.0103 & .0103 & 114 & - & 177 \\
375.01 & .0006 & -.006 & .0061 & 162 & $\mathrm{~B}$ & 175 \\
382.00 & .0029 & -.0137 & .014 & 297 & $\mathrm{~B}$ & 168 \\
385.01 & .002 & -.018 & .0181 & 336 & $\mathrm{~B}$ & 174 \\
$390.01 *$ & .0044 & -.0208 & .0213 & 341 & $\mathrm{~B}$ & 168 \\
$395.00^{*}$ & .0042 & -.0233 & .0237 & 326 & $\mathrm{~B}$ & 170 \\
397.00 & .0035 & -.0217 & .0219 & 306 & $\mathrm{~B}$ & 171 \\
398.00 & .0035 & -.0193 & .0196 & 320 & $\mathrm{~B}$ & 170 \\
$400.00^{* *}$ & .0011 & -.0158 & .0158 & 269 & $\mathrm{~B}$ & 176 \\
402.00 & .0029 & -.0129 & .0132 & 18 & $\mathrm{~B}$ & 167 \\
405.00 & .0031 & -.0119 & .0123 & 7 & $\mathrm{~B}$ & 165 \\
$415.00^{*}$ & .0046 & -.0176 & .0182 & 242 & $\mathrm{C}$ & 165 \\
$425.01 *$ & .0046 & -.0174 & .0179 & 303 & $\mathrm{C}$ & 165 \\
427.00 & .002 & -.0233 & .0234 & 206 & $\mathrm{C}$ & 175 \\
$430.00 *$ & .0047 & -.0166 & .0125 & 81 & - & 158 \\
\hline & & & & & &
\end{tabular}

Figure 4. Velocity-vector definitions used for intraborehole flow measured by the borehole acoustic doppler velocimeter. 
Table 2. Flow measurements in MW 3-2 (MW 3-2-030100), March 1, 2000, Mountain Home Air Force Base, Idaho

[Flow units are grouped by similar azimuths and depths; depth, feet below land surface; ft/s, feet per second; deg, degrees; B, water-bearing zone; *, data processed with signal-to-noise and data correlation filters removed]

\begin{tabular}{ccccccc}
\hline Depth & $\begin{array}{c}\text { Lateral } \\
(\mathbf{f t} / \mathbf{s})\end{array}$ & $\begin{array}{c}\text { Vertical } \\
(\mathrm{ft} / \mathbf{s})\end{array}$ & $\begin{array}{c}\text { Bulk } \\
(\mathrm{ft} / \mathbf{s})\end{array}$ & $\begin{array}{c}\text { Azimuth } \\
(\mathbf{d e g})\end{array}$ & $\begin{array}{c}\text { Flow } \\
\text { unit }\end{array}$ & $\begin{array}{c}\text { Dip } \\
(\mathbf{d e g})\end{array}$ \\
\hline 400.00 & 0.0151 & -0.0125 & 0.0196 & 3 & $\mathrm{~B}$ & 130 \\
405.00 & .0154 & -.0081 & .0174 & 300 & $\mathrm{~B}$ & 118 \\
410.00 & .0046 & -.0074 & .0087 & 311 & $\mathrm{~B}$ & 148 \\
$415.00^{*}$ & .0100 & -.0087 & .0132 & 339 & $\mathrm{~B}$ & 131 \\
$420.00^{*}$ & .0024 & -.0032 & .0040 & 300 & $\mathrm{~B}$ & 143 \\
$425.00^{*}$ & .0032 & -.0057 & .0066 & 358 & $\mathrm{~B}$ & 151 \\
$426.00 *$ & .0038 & -.0065 & .0075 & 293 & $\mathrm{~B}$ & 150 \\
$427.00^{*}$ & .0028 & -.0083 & .0088 & 315 & $\mathrm{~B}$ & 161 \\
\hline
\end{tabular}

ably less fractured layer of rock located between 400 and $402 \mathrm{ft}$ (fig. 5, borehole diameter log). Azimuthal data for the velocity profile vary dramatically and sometimes contradict directions of flow shown on 1990 water-level maps (fig. 1). However, water-level maps and the distribution of hydraulic head they represent generally reveal only regional-scale distributions of potential energy throughout a basin. The B-ADV is capable of measuring borehole-scale ground-water flow rates and directions, a level of detail that generally cannot be discriminated on maps that are derived from vertically composite water levels measured in wells over large areas. Water-level maps are useful as a regionalscale guide for comparison purposes but not necessarily as a reference for local-scale ground-water flow directions.

On the basis of the B-ADV data, ground-water flow directions at well MW11-2 appear to be separated into three distinct units (fig. 5, table 1). The upper waterbearing zone, unit $\mathrm{A}$, is from 361 to $368 \mathrm{ft}$ below land surface. Lateral flow directions in this zone are to the east and average $0.0031 \mathrm{ft} / \mathrm{s}$ at depths of 366 and $368 \mathrm{ft}$. Below unit $\mathrm{A}$ is a potential confining unit from 370 to $375 \mathrm{ft}$. Both of these lateral flow measurements are near the low-end resolution capability of the ADV. Flow directions in the second water-bearing zone, unit B, from 380 to $405 \mathrm{ft}$, are predominately to the northnorthwest toward Canyon Creek (fig. 1). Flow directions in the third and deepest zone, unit $\mathrm{C}$, from 415 to $427 \mathrm{ft}$, are predominately to the south-southwest toward the Snake River. The vertical flow component is as much as an order of magnitude larger than the lateral flow in well MW11-2. This indicates downward intraborehole flow between the upper and lower water-bearing zones and suggests the presence of downward vertical hydraulic head gradients and flow in the saturated rocks penetrated by these boreholes. This downward flow may have important implications for potential contaminant remediation.

Well MW3-2 is located approximately 5 mi north of the Snake River and 3 mi east of Canyon Creek (fig. 1). Two separate flow measurements were collected on different days. The first B-ADV log of MW3-2 was completed March 1, 2000, and is referred to as MW3-2-030100. The second log was completed March 3, 2000, and is referred to as MW3-2-030300. The log on March 1 measured flow in the interval between 400 and $427 \mathrm{ft}$ (table 2), and the log on March 3 measured flow between 390 and $435 \mathrm{ft}$ (table 3). Measurements made in MW3-2-030100 above $415 \mathrm{ft}$ meet the minimum SNR and COR requirements of 5 and 70, respectively (fig. 6).

Measurements made in MW3-2-030100 (fig. 6, table 2) and MW3-2-030300 (fig. 7, table 3) below $415 \mathrm{ft}$ are considered less reliable because less than 1 percent of the data met the minimum SNR and COR quality requirements. This was caused by a lack of acoustic scatterers suspended in the borehole and (or) turbulence in the borehole. For all measurements below $415 \mathrm{ft}$, the data-quality filters were removed and the resultant data were calculated for two reasons. First, the two logs share some common measurement points in the upper portions of the $\log$ (tables 2 and 3). Even though the velocity data for MW3-2-030300 appear to

Table 3. Flow measurements in MW 3-2 (MW 3-2-030300), March 3, 2000, Mountain Home Air Force Base, Idaho

[Flow units are grouped by similar azimuths and depths; depth, feet below land surface; ft/s, feet per second; deg, degrees; B, C, water-bearing zones; *, data processed with signal-to-noise and data correlation filters removed]

\begin{tabular}{crrrrrr}
\hline Depth & $\begin{array}{c}\text { Lateral } \\
(\mathrm{ft} / \mathbf{s})\end{array}$ & $\begin{array}{c}\text { Vertical } \\
(\mathrm{ft} / \mathbf{s})\end{array}$ & $\begin{array}{c}\text { Bulk } \\
(\mathrm{ft} / \mathbf{s})\end{array}$ & $\begin{array}{c}\text { Azimuth } \\
(\mathbf{d e g})\end{array}$ & $\begin{array}{c}\text { Flow } \\
\text { unit }\end{array}$ & $\begin{array}{r}\text { Dip } \\
(\mathbf{d e g})\end{array}$ \\
\hline 390.00 & 0.0073 & -0.0203 & 0.0216 & 289 & $\mathrm{~B}$ & 160 \\
400.00 & .0046 & -.0206 & .0211 & 285 & $\mathrm{~B}$ & 168 \\
402.00 & .0044 & -.0207 & .0212 & 322 & $\mathrm{~B}$ & 168 \\
403.00 & .0040 & -.0207 & .0211 & 311 & $\mathrm{~B}$ & 169 \\
404.50 & .0044 & -.0196 & .0201 & 288 & $\mathrm{~B}$ & 167 \\
407.00 & .0026 & -.0162 & .0164 & 4 & $\mathrm{~B}$ & 171 \\
410.00 & .0047 & -.0166 & .0172 & 331 & $\mathrm{~B}$ & 164 \\
412.00 & .0016 & -.0149 & .0150 & 276 & $\mathrm{~B}$ & 174 \\
414.00 & .0137 & -.0112 & .0177 & 342 & $\mathrm{~B}$ & 129 \\
$417.00^{*}$ & .0747 & -.0192 & .0071 & 168 & $\mathrm{C}$ & 76 \\
$420.00^{*}$ & .0172 & -.0003 & .0172 & 170 & $\mathrm{C}$ & 91 \\
$421.25^{*}$ & .0981 & -.0115 & .0988 & 342 & $\mathrm{C}$ & 97 \\
$423.00^{*}$ & .0395 & -.0026 & .0396 & 128 & $\mathrm{C}$ & 86 \\
$425.00^{*}$ & .0839 & -.0148 & .0852 & 131 & $\mathrm{C}$ & 80 \\
$427.00^{*}$ & .0185 & -.0028 & .0187 & 287 & $\mathrm{C}$ & 81 \\
$429.18^{*}$ & .0050 & -.0045 & .0068 & 61 & $\mathrm{C}$ & 132 \\
$431.19^{*}$ & .0327 & -.0005 & .0327 & 351 & $\mathrm{C}$ & 89 \\
$433.02 *$ & .0138 & -.0079 & .0159 & 279 & $\mathrm{C}$ & 120 \\
$435.10^{*}$ & .0217 & -.0010 & .0217 & 226 & $\mathrm{C}$ & 93 \\
\hline
\end{tabular}


be different than for MW3-2-030100, the lateral flow azimuth is generally the same-north-northwest. This north-northwest lateral flow direction is similar to that of lateral flow in unit B of MW11-2, which is toward Canyon Creek. Second, the direction of lateral flow in unit C of MW3-2-030300 is predominately southsouthwest toward the Snake River, similar to the direction of lateral flow in unit C of MW11-2. Downward flow that represents intraborehole flow is also present in MW3-2. Expanded geophysical and flow logs of MW11-2 and MW3-2 are shown in figures 8 and 9.

\section{SUMMARY AND CONCLUSIONS}

Both wells measured at Mountain Home Air Force Base exhibit variable flow regimes, including varying lateral velocities and directions of flow along individual borehole profiles. Perhaps this can be explained by the presence of local and regional flow regimes that are superimposed. Borehole acoustic doppler velocimeter data from unit B indicate that flow is toward Canyon Creek, occupies the upper portions of both measured wells, and may represent a more localscale flow regime. B-ADV data from unit $\mathrm{C}$ indicate that flow is toward the Snake River, occupies the lower portions of both measured wells, and may represent a more regional flow regime. Downward intraborehole flow also is occurring in these monitoring wells and may affect potential contaminant transport.

These borehole measurements made with the BADV have demonstrated its capability for measuring relatively slow-velocity ground-water flows and identifying potentially different flow regimes within the basalt ground-water system underlying the Mountain Home Air Force Base. This and additional flow and head data can be incorporated with water-chemistry data to aid in the study of contaminant transport on and near the Air Force Base, or on the regional scale of the basin. The data suggest that more information is needed to create a better conceptual model of local and regional ground-water flow regimes.
Although results of measurements demonstrate that flow directions are relatively consistent at the same depths in the two wells studied, additional flow measurements in more wells would better define this preliminary interpretation. The preferable well-location design for future studies that include drilling and geophysical logging would be three adjacent wells so that flow directions could be triangulated for assessment of potential differences between local- and regional-scale flow.

\section{REFERENCES CITED}

Newhouse, M.W., and Hanson, R.T., 2000, Application of three-dimensional borehole flow measurements to the analysis of seawater intrusion and barrier injection systems, Los Angeles, California, in Seventh International Symposium on Borehole Geophysics for Minerals, Geotechnical, and Groundwater Applications, Proceedings: The Minerals and Geotechnical Logging Society, October 24-26, 2000.

Ursic, James, 1996, Modified ADV for 3D velocity measurements in boreholes: U.S. Environmental Protection Agency, Final Project Report, U.S. Geological Survey Contract Number 1434-95-C-40232.

Wilson, J.T., Mandell, W.A., Paillet, F.L., Bayless, E.R., Hanson, R.T., Kearl, P.M., Kerfoot, W.B., Newhouse, M.W., and Pedler, W.H., 2001, An evaluation of borehole flowmeters used to measure horizontal ground-water flow in limestones of Indiana, Kentucky, and Tennessee, 1999: U.S. Geological Survey Water-Resources Investigations Report 01-4139, $129 \mathrm{p}$.

Young, H.W., Parliman, D.J., and Jones, M.L., 1992, Seasonal changes in ground-water quality and groundwater levels and directions of ground-water movement in southern Elmore County, southwestern Idaho, including Mountain Home Air Force Base, 1990-91: U.S. Geological Survey Water-Resources Investigations Report 92-4027, 2 sheets and accompanying table, $22 \mathrm{p}$.

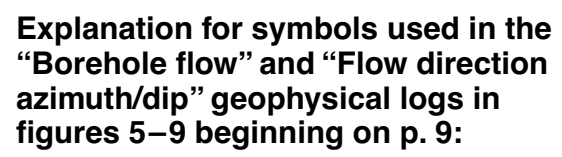

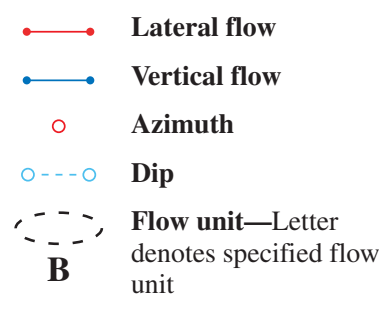




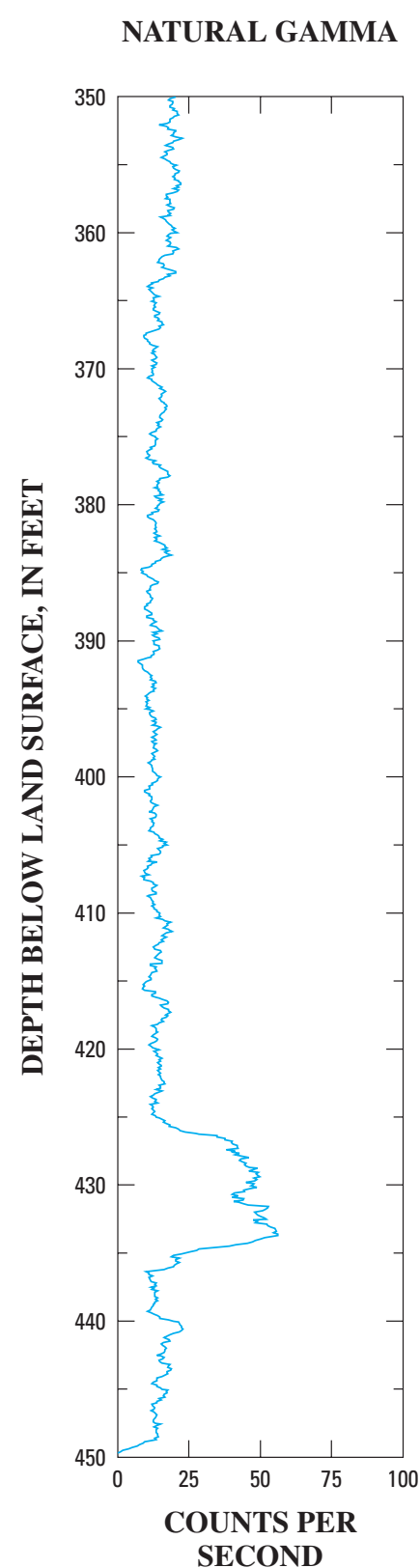

ELECTROMAGNETIC
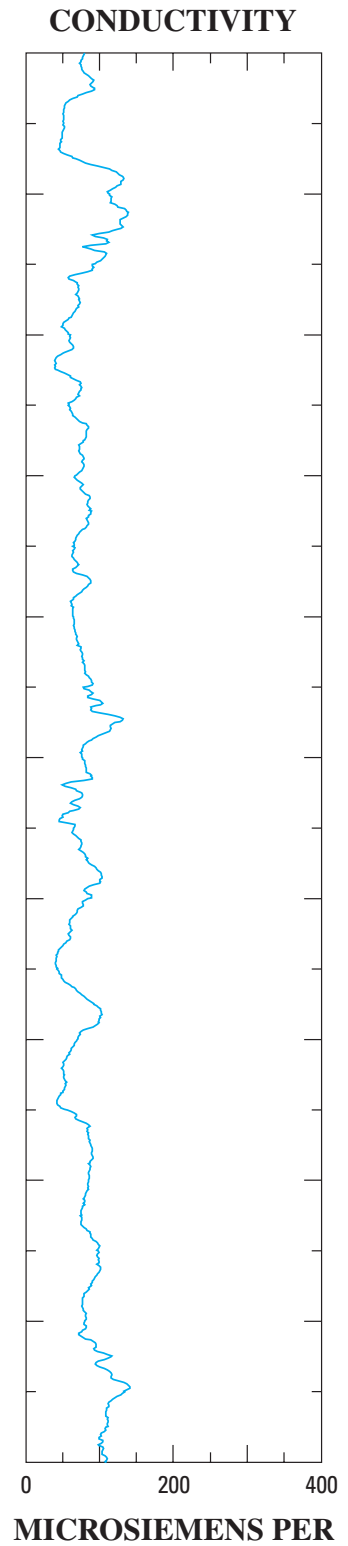

CENTIMETER
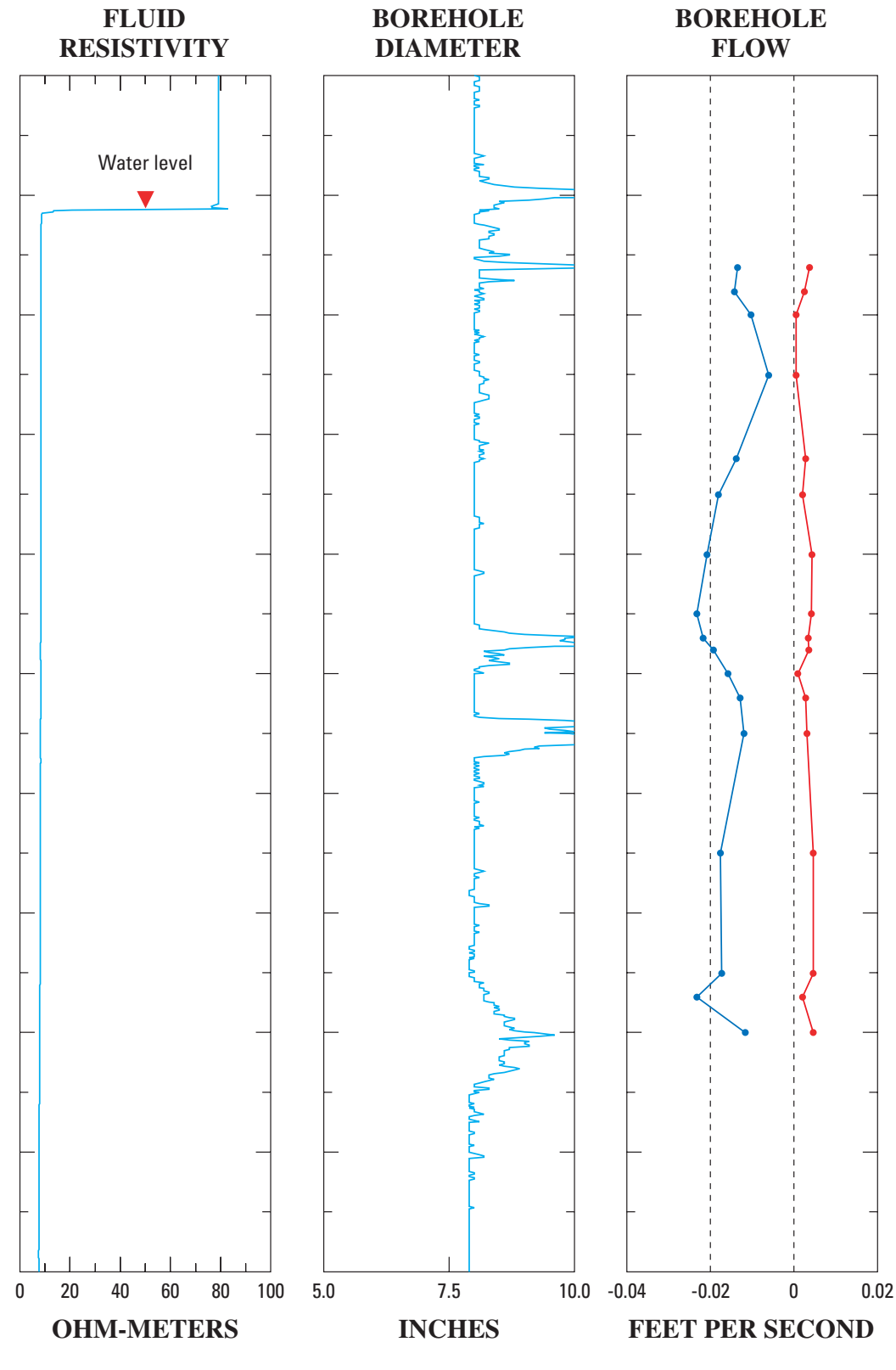

FLOW DIRECTION

AZIMUTH/DIP

North East South West North

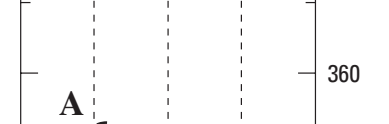

A

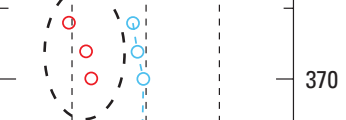

- $\begin{array}{rlll}1 & 1 & \\ -1 & & \\ 1 & & \\ & & \end{array}$

B -180

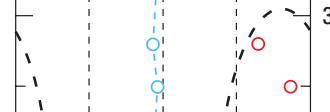

$\begin{array}{r:lll}1 & & 1 & \\ -1 & 1 & 1 & 0 \\ 1 & & & \end{array}$

$\begin{array}{r:ll:l}1 & 1 & 1 & \\ -1 & 0 & 1 & 0\end{array}$

$\begin{array}{rrrrr}1 & 0 & 1 & 0 \\ 1 & 1 & 1 & 0 \\ -1 & 0 & 1 & 0 & \end{array}$

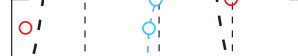
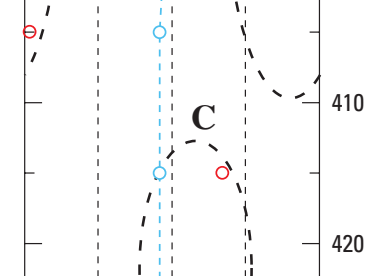
SECOND

Figure 5. Geophysical logs for MW11-2, 350 to 450 feet, Mountain Home Air Force Base, Idaho. 

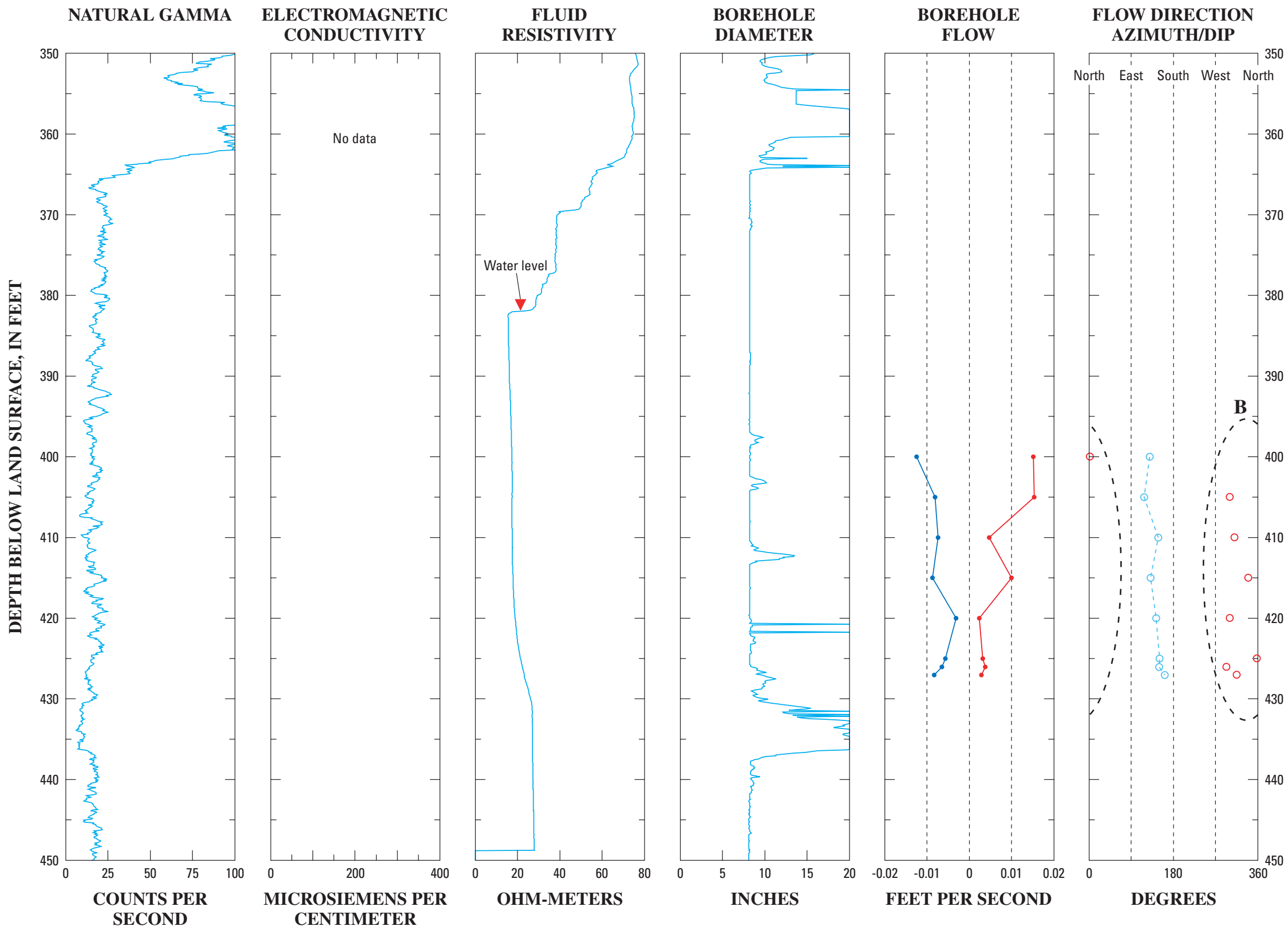

Figure 6. Geophysical logs for MW3-2 (MW3-2-030100), 350 to 450 feet, March 1, 2000, Mountain Home Air Force Base, Idaho 

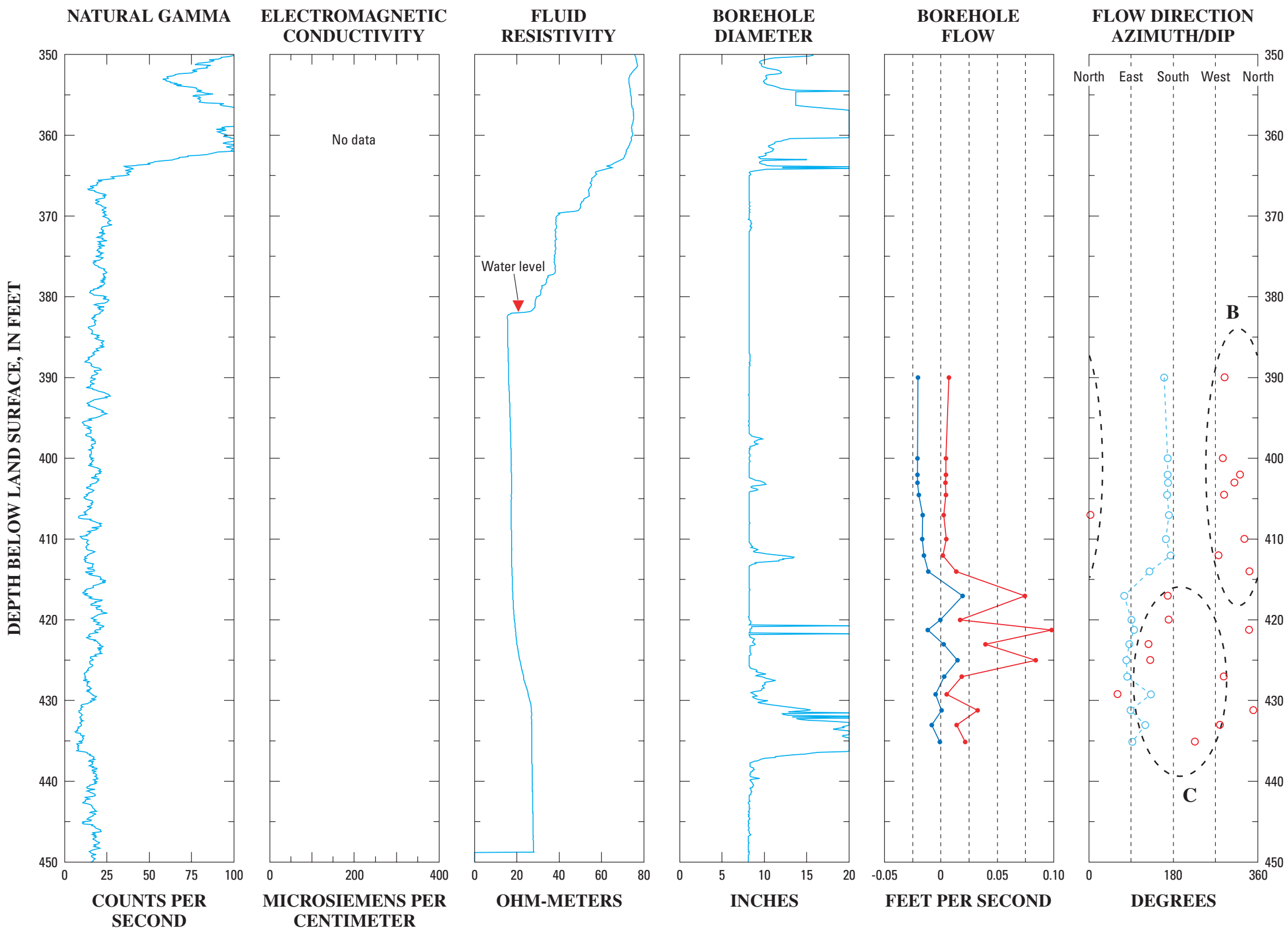

Figure 7. Geophysical logs for MW3-2 (MW3-2-030300), 350 to 450 feet, March 3, 2000, Mountain Home Air Force Base, Idaho. 

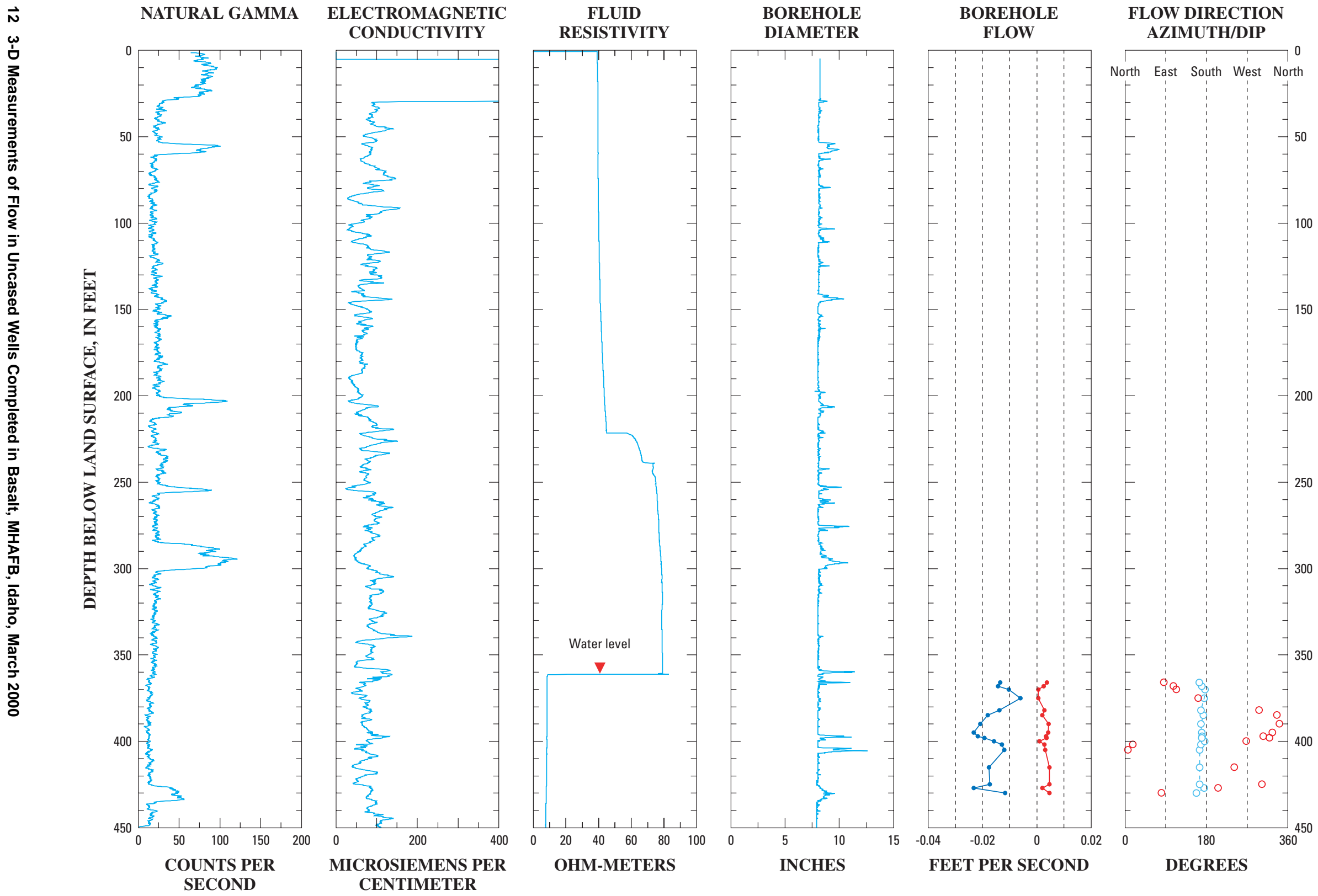

Figure 8. Geophysical logs for MW11-2, 0 to 450 feet, Mountain Home Air Force Base, Idaho 

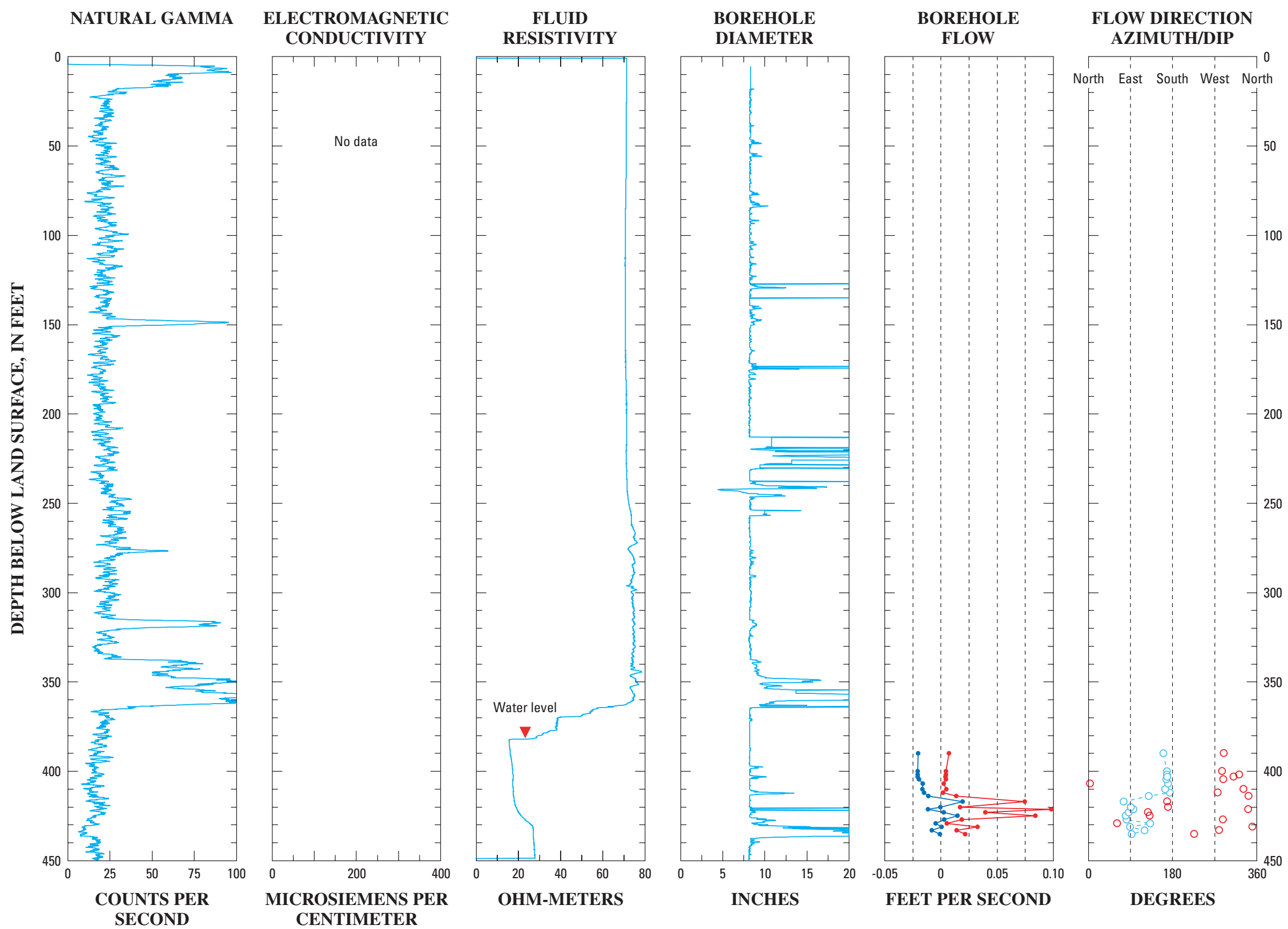

Figure 9. Geophysical logs for MW3-2, 0 to 450 feet, Mountain Home Air Force ase, Idaho. 


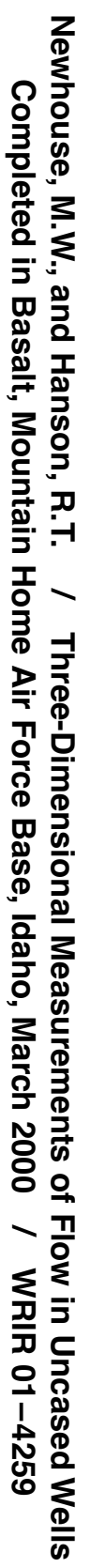

6 Printed on recycled paper 